\title{
Thrombocytopenic purpura as the sole manifestation of a recurrence of Hodgkin's disease
}

\author{
P. J. HAMILTON AND AUDREY A. DAWSON \\ From the Haematology Unit, Department of Pathology, University of Aberdeen
}

SYNOPSIS A man with apparently quiescent Hodgkin's disease presented with acute severe isolated thrombocytopenic purpura. Splenectomy revealed macroscopic involvement with Hodgkin's tissue and cured the thrombocytopenia.

In the absence of marrow involvement by disease, or depression by drugs, the platelet count in Hodgkin's disease, if disturbed, has generally been found to be increased (Hoster, Dratman, Craver, and Rolnick, 1948). Indeed, a raised platelet count may be a useful indicator of the disease activity, particularly in the absence of any external evidence of the disease process (Barry, Laroche, and Delâge, 1966). Thrombocytopenia, however, without any other depression of haematopoietic elements is distinctly rare, and it may thus be of some interest to detail a case of apparent idiopathic thrombocytopenic purpura which proved the only herald of a relapse of Hodgkin's disease.

\section{Case Report}

R.C., a 23-year-old Orcadian male, presented in September 1968 with six weeks' asthenia and anorexia. He had noticed for six months a progressively enlarging, painless mass in the right axilla. There was no pyrexia, nor other lymphadenopathy, and a chest radiograph was normal. The haemoglobin was $12.7 \mathrm{~g} / 100 \mathrm{ml}$, WBC $5800 / \mathrm{cmm}$, platelets $299000 /$ $\mathrm{cmm}$. Biopsy of the lump showed it to be matted lymph nodes. The axilla was partly cleared and five lymph nodes weighing $80 \mathrm{~g}$ were removed. Histologically, the lymph nodes were completely replaced with a mixed cellular infiltrate of eosinophils, plasma cells, and many Reed Sternberg cells; fibrosis was scanty. There was invasion of the capsule of two nodes. The diagnosis was Hodgkin's disease of mixed cellularity. He was treated with radiotherapy, receiving $3000 \mathrm{R}$ central dose to the right axilla over two weeks.

He returned to his employment as a lorry driver, well and free of evidence of disease. One year later, a $1.5 \mathrm{~cm}$ mobile, soft lymph node was noted in the Received for publication 24 October 1972. right supraclavicular region, but was not thought of significance. In August 1970, some two years after initial presentation, there was sudden enlargement of the right supraclavicular nodes, associated with a soft indefinite swelling infraclavicularly. A chest radiograph was again normal. Cobalt telotherapy (3000 R in a fortnight) cleared the swellings and he remained well without lymphadenopathy.

In October 1971 he presented with one day's haematuria, petechiae over the shoulders, arms, and inside the mouth. For 10 days previously, he had received ampicillin for a slightly sore throat, which was almost certainly due to petechiae of the buccal mucosa and tongue. In the previous fortnight he had noted slight itch but had suffered no chills, night sweats nor weight loss. Up to one month before admission he had been exposed to petrol and refrigeration plant fumes. Examination revealed no abnormality but the petechiae and a few tiny nodes in both cervical and axillary regions.

Haemoglobin was $13.6 \mathrm{~g} / 100 \mathrm{ml}$, white count $6000 / \mathrm{cmm}$, platelets $3000 / \mathrm{cmm}$, bleeding time (Duke's method) 30 minutes. Serum electrolytes, bilirubin, alkaline phosphatase, protein electrophoresis, and liver function tests were all within normal limits. Blood group was $\mathrm{O}$ Rhesus positive, a direct antiglobulin test was negative and no cold autoagglutinins were detected. Platelet and leucocytes agglutinins were absent, indirect antiglobulin consumption and complement-fixation tests for incomplete platelet antibodies were all negative. The leucocyte alkaline phosphatase score was low normal, and the antinuclear factor was negative. A chest radiograph, and radiographs of thoracic and lumbar spine and pelvis were all normal.

He was treated with immediate corticosteroid therapy; hydrocortisone $100 \mathrm{mg}$ intravenously and then prednisolone $60 \mathrm{mg}$ orally daily. There was no haematological improvement and eight days later he 
suffered epistaxis and a significant bleed into his right elbow; ACTH, 40 units im daily, was added but with no improvement, and after a week, azathioprine $175 \mathrm{mg}$ daily was introduced and the steroids slightly reduced to prednisolone $40 \mathrm{mg}$ daily and ACTH 40 units im on alternate days. Sternal marrow aspiration immediately before the introduction of the azathioprine showed a highly cellular marrow with normoblastic and moderately hyperplastic erythropoiesis and normal white cell precursors. Megakaryocytes were markedly hyperplastic, many granular, some promegakaryocytes, and none producing platelets. There was no evidence of Hodgkin's disease in the marrow. Three days after commencing azathioprine he suffered an epistaxis and had four days of melaena requiring 4 units of red cell concentrate. With failure to obtain any significant haematological improvement after 30 days' steroids and 16 days' azathioprine and with increasing problems with oropharyngeal moniliasis and follicular pustular acne, splenectomy was recommended and performed under cover of platelet concentrate transfusions in late November 1971.

At laparotomy a slightly enlarged and macroscopically normal spleen was found weighing $195 \mathrm{~g}$. Two fleshy white lymph nodes, $2 \mathrm{~cm}$ in diameter, were noted at the splenic hilum. No paraaortic nodes were found. Liver biopsy was undertaken. Haemorrhage was not a troublesome feature of the operation.

The spleen was studded with $1 \mathrm{~cm}$ white nodules throughout the red pulp. Histologically, the nodules were made up of Hodgkin's tissue of very similar appearance to the initial lymph node biopsies, with a very mixed cellular infiltrate. One of the splenic lymph nodes was completely replaced by Hodgkin's tissue, the other partly replaced. The liver biopsy was entirely normal.

The postoperative course was uneventful and within five days of splenectomy the platelet count had risen to $700000 / \mathrm{cmm}$. He has subsequently remained well apart from a superficial thrombophlebitis of the left arm postoperatively. He is currently being treated with cyclical courses of quadruple chemotherapy: mustine, vinblastine, procarbazine and prednisolone. There is no detectable lymphadenopathy, the chest radiograph remains normal and his ESR is only $6 \mathrm{~mm} /$ hour (Westergen). The platelet count varies between $200000 / \mathrm{cmm}$ and $400000 / \mathrm{cmm}$.

\section{Discussion}

Splenectomy in this patient was not undertaken in search of Hodgkin's tissue but was performed as a life-saving procedure when steroids, ACTH, and immunosuppressive therapy had produced no remission of the thrombocytopenia. It is becoming widely appreciated, however, that the certain detection of Hodgkin's infiltration of the spleen or upper abdominal lymph nodes clinically or radiologically is not possible (Rosenberg, 1971). Nevertheless the abdominal involvement in this man was not surprising, for there was previous clinical involvement of supraclavicular nodes in histologically proven 'mixed cellularity' Hodgkin's disease, features known to predispose to subdiaphragmatic extension of the disease (Peters, 1971). Also, the radiation dosage and fields were smaller than the standard radiotherapy techniques now employed (Kaplan, 1966).

While autoimmune thrombocytopenic purpura is readily recognized as complicating the course of chronic lymphatic leukaemia (Ebbe, Wittels, and Dameshek, 1962) and lymphomas (Harrington, Minnich, and Arimura, 1956), isolated thrombocytopenia of this type is a distinct rarity in Hodgkin's disease. Only 10 cases have been reported and these as brief mentions in surgical series (Perlman and Fox, 1941; Williams, Andrews, and Zanes, 1951; Reinhard and Loeb, 1955; Rousselot, Rella, and Rottino, 1962). The only fully described case of thrombocytopenic purpura in Hodgkin's disease (Gledhill and Shillitoe, 1952) seems to belong to the group of cases associated with gross splenomegaly and pancytopenia, recently reviewed by Lowenbraun, Ramsey, and Serpick, 1971). This paucity of cases of isolated thrombocytopenic purpura in Hodgkin's disease is presumably a reflection of the much less common tendency to antibody formation in this disorder than in the lymphoproliferative diseases. Perhaps there is a difference in balance between cellular immunity to platelets and the serum factor which blocks delayed-type hypersensitivity (Clancy, 1972 ) in the two groups of diseases. In this case no antiplatelet antibodies were detected in vitro but the platelet count recovered after splenectomy in the manner of a true 'idiopathic' thrombocytopenic purpura and there has been no recurrence of the thrombocytopenia.

We are grateful to Dr E. F. Ridley and the staff of the malignant disease unit for willing access to their records, to Mr P. F. Jones for his help with splenectomy, and to Dr A. J. Carr for reviewing the histology of the case.

\section{References}

Barry, A., Laroche, A., and Delâge, J. M. (1966). Les plaquettes sanguines dans la maladie de Hodgkin. Laval Méd., 37, 784-787.

Clancy, R. (1972). Cellular immunity to autologous platelets and serum-blocking factors in idiopathic thrombocytopenic purpura. Lancet, 1, 6-9. 
Ebbe, S., Wittels, B., and Dameshek, W. (1962). Autoimmune thrombocytopenic purpura ('I.T.P.' type) with chronic lymphatic leukaemia. Blood, 19, 23-27.

Gledhill, R. C., and Shillitoe, A. J. (1952). Purpura and amyloidosis in Hodgkin's disease. Brit. med. J., 1, 1336-1337.

Harrington, W. J., Minnich, V., and Arimura, G. (1956). The autoimmune thrombocytopenias. Progr. Haemat., 1, 166-192.

Hoster, H. A., Dratman, M. B., Craver, L. F., and Rolnick, H. A. (1948). Hodgkin's disease Part I, 1832-1937. Cancer Res., 8, $1-48$.

Kaplan, H. S. (1966). Long-term results of palliative and radical radiotherapy of Hodgkin's disease. Cancer Res., 26, 1250-1253.

Lowenbraun, S., Ramsey, H. E., and Serpick, A. A. (1971). Splenectomy in Hodgkin's disease for splenomegaly, cytopenias and intolerance to myelosuppressive chemotherapy. Amer. J. med., 50, 49-55.
Perlman, L., and Fox, T. A. (1941). Hemorrhagic diatheses. Arch. intern. Med., 68, 112-120.

Peters, M. V. (1971). The need for a new clinical classification in Hodgkin's disease. Cancer Res., 31, 1713-1722.

Reinhard, E. H., and Loeb, V. (1955). Dyssplenism secondary to chronic lymphatic leukaemia or malignant lymphoma.J. Amer. med. Ass., 158, 629-634.

Rosenberg, S. A. (1971). A critique of the value of laparotomy and splenectomy in the evaluation of patients with Hodgkin's disease. Cancer Res., 31, 1737-1740.

Rousselot, L. M., Rella, A. J., and Rottino, A. (1962). Splenectomy for hypersplenism in Hodgkin's disease. Amer. J. Surg., 103, 769-774.

Williams, R. D., Andrews, N. C., and Zanes, R. P., Jr. (1951). Major surgery in Hodgkin's disease. Surg. Gynec. Obstet., 93, 636-640.

\section{Reports and Bulletins prepared by the Association of Clinical Biochemists}

The following reports and bulletins are published by the Association of Clinical Biochemists. They may be obtained from The Administrative Office, Association of Clinical Biochemists, 7 Warwick Court, Holborn, London, WC1R 5DP. The prices include postage, but air mail will be charged extra. Overseas readers should remit by British Postal or Money Order. If this is not possible the equivalent of $50 \mathrm{p}$ is the minimum amount that can be accepted.

\section{SCIENTIFIC REPORTS}

3 Automatic Dispensing Pipettes. An assessment of 35 commercial instruments 1967 P. M. G. BROUGHTON, A. H. GOWENLOCK, G. M. WIDDOWSON, and K. A. AHLQUIST 80p (\$2)

4 An Evaluation of five Commercial Flame Photometers suitable for the Simultaneous Determination of Sodium and Potassium March 1970 P. M. G. BROUGHTON and J. B. DAWSON 80p (\$2)

SCIENTIFIC REVIEWS

1 The Assessment of Thyroid Function March 1971 F. V. FLYNN and J. R. HOBBS 60p (\$1.50)

2 Renal Function Tests Suitable for Clinical Practice January 1972 F. L. MTTCHeLl, N. VEALL, and R. W. E. WATTS 60p (\$1.50)

\section{TECHNICAL BULLETINS}

9 Determination of Urea by AutoAnalyzer November 1966 RUTH M. HASLAM 40p (\$1)

11 Determination of Serum Albumin by AutoAnalyzer using Bromocresol Green October 1967 B. E. NORTHAM and G. M. WIDDOWSON 40p (\$1)

13 An Assessment of the Technicon Type II Sampler Unit March 1968 B. C. GRAY and G. K. McoowAN 40p (\$1)

14 Atomic Absorption Spectroscopy. An outline of its principles and a guide to the selection of instruments May 1968 J. B. DAWSON and P. M. G. BROUGrTON 40p (\$1)

15 A Guide to Automatic Pipettes (2nd edition) June 1968 P. M. G. BROUGHTON 40p (\$1)
16 A Guide to Automation in Clinical Chemistry May 1969 P. M. G. BROUGHTON 60p (\$1.50)

17 Flame Photometers (2nd edition) 1969 P. WILDING 60p (\$1.50)

18 Control Solutions for Clinical Biochemistry (4th edition) March 1970 P. M. G. BROUGHTON 60p (\$1.50)

19 Spectrophotometers. A comparative list of low-priced instruments readily available in Britain May 1970 C. E. WLDE and P. SEWELL 60p (\$1.50)

20 Quantities and Units in Clinical Biochemistry June 1970 P. M. G. BROUGHTON 60p (\$1.50) More than 30 copies in units of 10 at 20p

21 Filter Fluorimeters: A comparative list of 18 instruments September 1970 H. BRAUNSBERG and S. S. BROWN 60p (\$1.50)

22 Bilirubin standards and the Determination of Bilirubin by Manual and Technicon AutoAnalyzer Methods January 1971 BARBARA BILLING, RUTH HASLAM, and N. WALD 60p (\$1.50)

23 Interchangeable Cells for Spectrophotometers and Fluorimeters September 1971 E. S. BROWN and A. H. GOWENLOCK 60p (\$1.50)

24 Simple Tests to Detect Poisons March 1972 B. w. MEADE et al. $60 \mathrm{p}(\$ 1.50)$

25 Blood Gas Analysers May 1972 k. DixoN 60p $(\$ 1.50)$

26 Kits for Enzyme Activity Determination September 1972 S. B. ROSALKI and D. TARLOW 80p (\$2.00)

27 Assessment of Pumps Suitable for Incorporation into Existing Continuous Flow Analytical Systems November 1972 A. FLECK et al 60p (\$1.50) 